\title{
Evaluation of tropospheric ozone reanalyses with independent ozonesonde observations in East Asia
}

Sunmin Park ${ }^{1}$, Seok-Woo Son ${ }^{1 *}$, Myung-II Jung ${ }^{1}$, Jinkyung Park ${ }^{1}$ and Sang Seo Park ${ }^{2}$

\begin{abstract}
The modern reanalysis datasets provide not only meteorological variables, but also atmospheric chemical compositions such as tropospheric ozone and aerosol concentration. However, the quality of chemical compositions has been rarely assessed especially over East Asia. To better understand the characteristics of reanalysis datasets on regional scale, the present study evaluates tropospheric ozone derived from seven reanalyses against five independent ozonesonde observations in East Asia. The reanalysis datasets are the ECMWF Reanalysis 5th (ERA5), Monitoring Atmospheric Composition and Climate reanalysis (MACCRA), Copernicus Atmosphere Monitoring Service reanalysis (CAMSRA), as well as the NCEP Climate Forecast System Reanalysis (CFSR), NASA Modern-Era Retrospective analysis for Research and Applications version 2 (MERRA2), Japanese 55-year Reanalysis (JRA-55), and updated Tropospheric Chemistry Reanalysis (TCR-2). It turns out that MACCRA, CAMSRA, and TCR-2, which incorporate chemical transport model, depict most reasonable spatio-temporal variability of tropospheric ozone in East Asia. The MACC exhibits a better quality with relatively small mean biases of $6.4 \pm 1.3 \%$ in tropospheric column ozone than biases of $7.8 \pm 2.7 \%$ and $7.8 \pm 2.8 \%$ for CAMSRA and TCR-2. The CAMSRA further shows a significant monthly correlation with the observation of up to 0.7 at $850 \mathrm{hPa}$. Among the seven reanalyses, MACC, CAMSRA, and TCR-2 are suitable for local tropospheric ozone study on seasonal to inter-annual time scales. However, none of the seven reanalysis datasets reproduce the observed trend of tropospheric ozone. This result suggests that even the latest datasets are inadequate for the long-term ozone change study.
\end{abstract}

Keywords: Tropospheric ozone, Ozonesonde, Reanalysis evaluation

\section{Introduction}

Tropospheric ozone is an important trace gas in the atmosphere. It is primarily generated by the local photochemical production from natural and anthropogenic sources and the input from the stratosphere. Its concentration is highly variable in space and time due to the various emission sources, complicated chemical processes, atmospheric transports, and other influences of meteorological conditions (e.g., Ramsey et al. 2014). Although a relatively small amount compared to stratospheric ozone,

\footnotetext{
${ }^{*}$ Correspondence: seokwooson@snu.ac.kr

${ }^{1}$ School of Earth and Environmental Sciences, Seoul National University, 1

Gwanak-ro, Gwanak-gu, Seoul 08826, South Korea

Full list of author information is available at the end of the article
}

tropospheric ozone affects weather and climate systems as a short-lived climate forcer (Monks et al. 2015; Scott et al. 2018). For instance, tropospheric ozone directly and indirectly influences atmospheric radiation. The indirect impact is realized through its impact on carbon uptake by the reduction of vegetation productivity (Lombardozzi et al. 2015) and methane lifetime (Fiore et al. 2008). According to the IPCC report (Myhre et al. 2013), the estimated radiative forcing due to tropospheric ozone is 0.2 to $0.6 \mathrm{~W} \mathrm{~m}^{-2}$ in the present climate.

Atmospheric reanalysis datasets provide global tropospheric ozone data in high spatial and temporal resolutions by assimilating diverse satellite observations. However, there remain considerable discrepancies 
between the reanalyses and in situ observations especially in the lower troposphere (i.e., Flemming et al. 2017). The ozone product from Monitoring Atmospheric Composition and Climate reanlaysis (MACCRA), for instance, shows significant biases in the diurnal and seasonal cycles of the near-surface ozone in Europe (Katragkou et al. 2015). Wargan et al. (2017) also indicated that the use of Modern-Era Retrospective Analysis for Research and Applications version 2 (MERRA2) ozone product needs a caution for decadal change and long-term trend studies.

Despite many previous studies, no studies have assessed the quality of tropospheric ozone reanalysis product in East Asia against independent observations. It is unclear whether the latest reanalyses reproduce the seasonality and inter-annual variability of tropospheric ozone in East Asia where local emissions are substantially large. A few recent studies reported an overall increasing trend of tropospheric ozone in East Asia since the year 2000 (Parrish et al. 2014; Gaudel et al. 2018). However, such a trend is not evaluated from the reanalysis datasets.

The goals of the present study are (1) to evaluate the tropospheric ozone concentration from seven reanalysis datasets using five long-term ozonesonde measurements in East Asia, and (2) to suggest the proper usage of reanalysis tropospheric ozone. "Data and methods" section describes the data and methods, and "Results and discussion" section discusses the results, including the evaluation of ozone vertical profile, seasonal cycle and long-term trend of 850-hPa ozone concentration. Summary is provided in "Conclusions" section.

\section{Data and methods}

The seven reanalysis datasets, which provide ozone vertical profile, are examined (Table 1). They are the ECMWF Reanalysis 5th (ERA5), MACCRA, Copernicus
Atmospheric Monitoring Service Reanalysis (CAMSRA), NCEP Climate Forecast System Reanalysis (CFSR), Japanese 55-year Reanalysis (JRA-55), MERRA2, and updated Tropospheric Chemistry Reanalysis (TCR-2). All datasets are evaluated for the common period of 2003-2012 except for trend analysis. The long-term trends are examined for the two time periods, i.e., the common period of 2003-2012 and the extended period of 2003-2017 excluding CFSR and TCR-2 which provide shorter period of dataset. For these two reanalyses, we use all available datasets (Table 1). Only monthly-mean ozone profiles are examined.

The ERA5, MACCRA, and CAMSRA are generated by the ECMWF, but differ in the details. The ozone mass mixing ratio in ERA5 is produced by an updated version of the ozone parameterization of Cariolle and Deque (1986) scheme as described by Cariolle and Teyssèdre (2007). This scheme linearly estimates ozone mass mixing ratio by considering temperature, stratospheric chlorine concentration, altitude, and season. The linear coefficients have been calculated using an external 2-D photochemical model. Various satellite observations, covering different time periods, are assimilated (Hersbach et al. 2019). Moreover, it applies a variation bias correction to ozone data.

The MACCRA and CAMSRA differ from ERA5 as they incorporate the chemical transport model. The MACCRA utilizes the ECMWF Integrated Forecasting System (IFS) coupling to the Model for Ozone and Related chemical Tracers version 3 (MOZART-3) chemical transport model (Flemming et al. 2009) and considers the production and loss of ozone, carbon monoxide, nitrogen oxides, formaldehyde, and others. Here IFS provides background meteorological fields and initial ozone concentration and MOZART-3 model computes chemical reactions, emissions, and depositions (Inness et al.

Table 1 Seven reanalysis datasets used in this study

\begin{tabular}{|c|c|c|c|c|c|c|c|}
\hline & \multirow[t]{2}{*}{ Source } & \multirow[t]{2}{*}{ Available period } & \multicolumn{2}{|l|}{ Used data period } & \multicolumn{2}{|l|}{ Native resolution } & \multirow[t]{2}{*}{ References } \\
\hline & & & $\begin{array}{l}\text { Spatial/vertical/ } \\
\text { seasonal distributions } \\
\text { and Taylor diagram }\end{array}$ & Long-term trend & Horizontal (lat* lon) & Vertical level & \\
\hline ERA5 & ECMWF & 1979.01-present & 2003.01-2012.12 & 2003.01-2017.12 & $0.25^{\circ} \times 0.25^{\circ}$ & L37 & Hersbach et al. 2019 \\
\hline MACCRA & & 2003.01-2012.12 & & 2003.01-2012.12 & $0.75^{\circ} \times 0.75^{\circ}$ & L22 & Inness et al. 2013 \\
\hline CAMSRA & & 2003.01-2018.12 & & 2003.01-2017.12 & $0.75^{\circ} \times 0.75^{\circ}$ & L25 & Inness et al. 2019 \\
\hline CFSR & NCEP & 1979.01-2010.12 & 2003.01-2010.12 & 2003.01-2010.12 & $0.5^{\circ} \times 0.5^{\circ}$ & L37 & Saha et al. 2010 \\
\hline JRA-55 & JMA & 1958.01-present & 2003.01-2012.12 & 2003.01-2017.12 & $0.5^{\circ} \times 0.5^{\circ}$ & L60 & Kobayashi et al. 2015 \\
\hline MERRA2 & NASA & 1980.01-2018.06 & 2003.01-2012.12 & 2003.01-2017.12 & $0.5^{\circ} \times 0.625^{\circ}$ & $\llcorner 42$ & Gelaro et al. 2017 \\
\hline TCR-2 & JAMSTEC & 2005.01-2017.12 & 2005.01-2012.12 & 2005.01-2017.12 & $1.1^{\circ} \times 1.1^{\circ}$ & L27 & $\begin{array}{l}\text { Miyazaki et al. 2019, } \\
2020 \\
\text { Kanaya et al. } 2019\end{array}$ \\
\hline
\end{tabular}


2013). The CAMSRA is the most recent ECMWF global reanalysis data for atmospheric composition. A modified and extended version of Carbon Bond (CB05) chemical mechanism, as implemented in the global chemistry transport model Tracer Model 5 (CTM TM5) (Yarwood et al. 2005; Huijnen et al. 2010) for troposphere, is used. The chemical mechanism describes tropospheric chemistry with 54 species and 126 reactions, and includes the chemistry routine related to tropospheric ozone (Inness et al. 2019).

All ECMWF reanalyses use the four-dimensional variational data assimilation to combine satellite observations with chemistry-aerosol modeling (Inness et al. 2013; 2019). For the ozone data assimilation, various ozone products, including ozone vertical profile, total column ozone and ozone partial column from multiple satellites are used. Among others, they include the Solar Backscatter Ultraviolet (SBUV), Ozone Monitoring Instrument (OMI), and Microwave Limb Sounder (MLS) datasets.

The other four reanalysis datasets, CFSR, MERRA2, JRA-55, and TCR-2, are provided from NCEP, NASA, JMA, and JAMSTEC, respectively. The CFSR considers ozone as a prognostic variable (Saha et al. 2010). The climatological ozone is analyzed and transported from a two-dimensional chemistry model, the Naval Research Laboratory CHEM2D-Ozone Photochemistry Parameterization (NRL CHEM2D-OPP) (McCormack et al. 2006). This model computes the ozone production and loss rates by considering local ozone mixing ratio, temperature, and overlying ozone vertical column density.

The MERRA2 is produced with the updated Goddard Earth Observing System (GEOS) atmospheric data assimilation system. No chemical transport model is incorporated in MERRA2. Instead it estimates ozone using a diurnally and height-varying relationship between ozone and prognostic odd oxygen in a two-dimensional chemistry model (Rienecker et al. 2008; Gelaro et al. 2017). More importantly, the chemical production or loss of tropospheric ozone is not considered and dry deposition is the only removal process at the surface. The assimilated ozone products in MERRA2 are ozone mixing ratio profiles, partial and total column ozone concentration from various satellite observations (Wargan et al. 2015, 2017).

The JRA-55 ozone data are produced in two methods over the two time periods. Before 1978, time-interpolated three-dimensional climatological monthly mean is used for the daily ozone distribution. An estimated daily mean three-dimensional ozone vertical profile, derived from the Meteorological Research Institute ChemistryClimate Model version 1 (MRI-CCM1) offline Chemical Transport Model (Shibata et al. 2005), is then applied from 1979 to the present (Kobayashi et al. 2015). It is produced separately from the data assimilation system. For data assimilation, a nudging scheme is applied using the total column ozone from Total Ozone Mapping Spectrometer (TOMS) on Nimbus-7 and OMI.

The tropospheric ozone from TCR-2 (Miyazaki et al. 2019, 2020; JAMSTEC 2019) is produced by assimilating a set of satellites of diverse atmospheric compositions into a global chemical model of the troposphere, named CHemical AGCM for Study of atmospheric Environment and Radiative forcing (CHASER). This model calculates 88 chemical and 25 photolytic reactions with 47 chemical species (Sudo et al. 2002). Moreover, it considers natural and anthropogenic emission sources of 10 chemical compounds (i.e., nitrogen oxides, carbon monoxide) to obtain basic chemical transformation of ozone. For the data assimilation, the Ensemble Kalman filter (EnKF) technique is applied (Hunt et al. 2007) using various satellites such as OMI, Tropospheric Emission Spectrometer's (TES), and Measurements of Pollution in the Troposphere (MOPITT).

The above seven reanalysis datasets are evaluated against long-term measurements of five ozonesonde stations in East Asia (Table 2). Here, East Asia is defined as the region between $15^{\circ}$ to $50^{\circ} \mathrm{N}$ latitude, and $100^{\circ}$ to $150^{\circ} \mathrm{E}$ longitude. The chosen stations are Hong Kong (HKO), Naha (NAH), Pohang (POH), Sapporo (SAP), and Tsukuba (TKB), ranging from $21.02^{\circ}$ to $43.06^{\circ} \mathrm{N}$ and from $105.83^{\circ}$ to $141.33^{\circ} \mathrm{E}$. Although additional stations

Table 2 Ozonesonde stations used in this study

\begin{tabular}{llllll}
\hline & Hongkong, China (HKO) & Naha, Japan (NAH) & Sapporo, Japan (SAP) & Tsukuba, Japan (TKB) & Pohang, Korea (POH) \\
\hline Latitude $\left(^{\circ}\right)$ & 22.31 & 26.21 & 43.06 & 36.06 & 36.03 \\
Longitude $\left(^{\circ}\right)$ & 114.17 & 127.68 & 141.33 & 140.13 & 129.38 \\
Altitude $(m)$ & 66 & 28 & 26 & 31 & 2.5 \\
Timestamp & OOUTC & 09UTC & 09UTC & 09UTC & 09UTC \\
Observation period & 2000.06-2017.12 & 1989.01-2018.01 & $1969.01-2018.01$ & $1968.01-2018.05$ & $1995.01-2017.12$ \\
Source & World Ozone and Ultraviolet Radiation Data Centre (WOUDC) & & Korea Meteorologi- \\
& & & & cal Administration \\
& & & & (KMA) \\
\hline
\end{tabular}


are available, only the stations which provide more than 10 years of dataset are examined in this study. All ozonesonde datasets are retrieved from the World Ozone and Ultraviolet Radiation Data Centre (WMO-GAW/ WOUDC 2013; http://www.woudc.org). The only exception is $\mathrm{POH}$ station whose ozone profiles are directly obtained from Korea Meteorological Administration (KMA; https://www.kma.go.kr). It is the longest ozonesonde station in Korea since 1995 (Kim et al. 2006).

None of these station observations are assimilated in the reanalyses. Each station launches ozonesonde at least once a week unless local weather condition is extreme. Hence all stations provide 1 to 13 ozone vertical profiles per month except for $\mathrm{POH}$ which has $1 \%$ missing data in monthly ozone profiles. The ozonesonde data carry about $7-17 \%$ measurement errors in the troposphere below 250 or $300 \mathrm{hPa}$ and $\pm 5 \%$ in the stratosphere from 200 to $10 \mathrm{hPa}$ (e.g., Beekman et al. 1994). Depending on region and season, these errors could become larger (Miyazaki and Bowman 2017). In spite of the measurement errors, the ozonesonde observations have been extensively used for ozone trend studies and model evaluations (e.g., WMO 2007).

It is also noteworthy that ozonesonde measurements in East Asia have a rather short history. Although some stations around the world have measured ozone profiles since the late 1970s, most stations over East Asia have started to measure ozone profiles only in the 1990s (Table 2). In this study, daily observations are used to compute the monthly-mean ozone profiles. Although the launching frequency of ozonesonde varies between stations, all available data in each month are simply averaged. If a single observation is not available, the monthlymean record is set to a missing value.

For a direct comparison, the unit of ozone concentration in both the reanalyses and observations is converted to ppbv. A comparison is conducted by analyzing ozonesonde with the reanalysis ozone in the grid box containing the ozonesonde station. In the vertical, only standard pressure level data are used with an emphasis on $850 \mathrm{hPa}$, which represents the characteristics of ozone from near surface to lower troposphere with a less topography impact over East Asia. As an alternative reference level, 500-hPa pressure level is also examined, but shown only in Additional file 1.

\section{Results and discussion}

Figure 1 presents spatial distribution of $850-\mathrm{hPa}$ ozone concentration over East Asia from the seven reanalysis datasets. It clearly shows that each reanalysis has substantially different climatological distribution. The four reanalysis datasets without chemical transport model (i.e., ERA5, CFSR, MERRA2, and JRA-55 shown in the left column) exhibit zonally elongated distribution. Their latitudinal patterns, however, are drastically different. While JRA-55 shows a latitudinally decreasing ozone concentration, ERA5, MERRA2, and CFSR show a maximum ozone concentration in midlatitudes. The source of this discrepancy is unknown.

All reanalyses incorporated with chemical transport model exhibit more localized ozone distribution, centered at eastern China where ozone precursor emissions are abundant. A decreasing ozone concentration on its downstream region in MACCRA, CAMSRA, and TCR-2 hints ozone transport from eastern China to Korea and Japan. This pattern is indeed consistent with westerly background wind in the region (Additional file 1: Fig. S1). As reported in the previous studies, tropospheric ozone can be transported from eastern China to Korea, Japan, and even to western United States through the prevailing westerly wind (Brown-Steiner and Hess 2011; Gaudel et al. 2018).

In Fig. 1, ozonesonde observations are overlaid on the reanalysis ozone values. Climatological ozone concentration ranges from $46.3 \mathrm{ppbv}$ in $\mathrm{HKO}$ at $\sim 22.3^{\circ} \mathrm{N}$ to $57 \mathrm{ppbv}$ in $\mathrm{POH}$ at $\sim 36^{\circ} \mathrm{N}$, and to $42.2 \mathrm{ppbv}$ in SAP at $\sim 43^{\circ} \mathrm{N}$ (Additional file 1: Table S1). This banded structure, largely resulting from ozone transport along the jet stream, reveals that lower-tropospheric ozone concentration over East Asia significantly varies with latitudes, local emissions, and background flows (Ding et al. 2008; Parrish et al. 2014).

The visual evaluation indicates that MACCRA, CAMSRA, and TCR-2 reasonably well capture the spatial distribution and amount of ozone concentration. Additional file 1: Table S1 shows 10-year climatology of $850-\mathrm{hPa}$ ozone concentration at each station, and the difference between each station and reanalysis. A majority of reanalysis datasets underestimate ozone at TKB and $\mathrm{POH}$ stations, located at $\sim 36^{\circ} \mathrm{N}$. In contrast, all reanalyses overestimate ozone at $\mathrm{NAH}$. It indicates that latitudinal bias exists in several reanalyses, although some reanalyses are able to depict the local emission and transport.

The detailed seasonal cycle of tropospheric ozone at $850 \mathrm{hPa}$ is further illustrated in Fig. 2. Most reanalysis data faithfully reproduce the observed seasonal cycle of 850-hPa ozone concentration. A notable underestimation appears from JRA-55, especially at the higher latitude stations. But, this data overestimates ozone concentration in most stations at $500 \mathrm{hPa}$ (Additional file 1: Fig. S2). The ERA5, CFSR, and MERRA2 also underestimate overall seasonality at most stations. Chemical transport model-based reanalyses, i.e., MACCRA, CAMSRA, and TCR-2, fairly well capture the observed seasonal cycle in quantity. Similar but better agreement between reanalyses and observation is found at $500 \mathrm{hPa}$ (Additional file 1: 

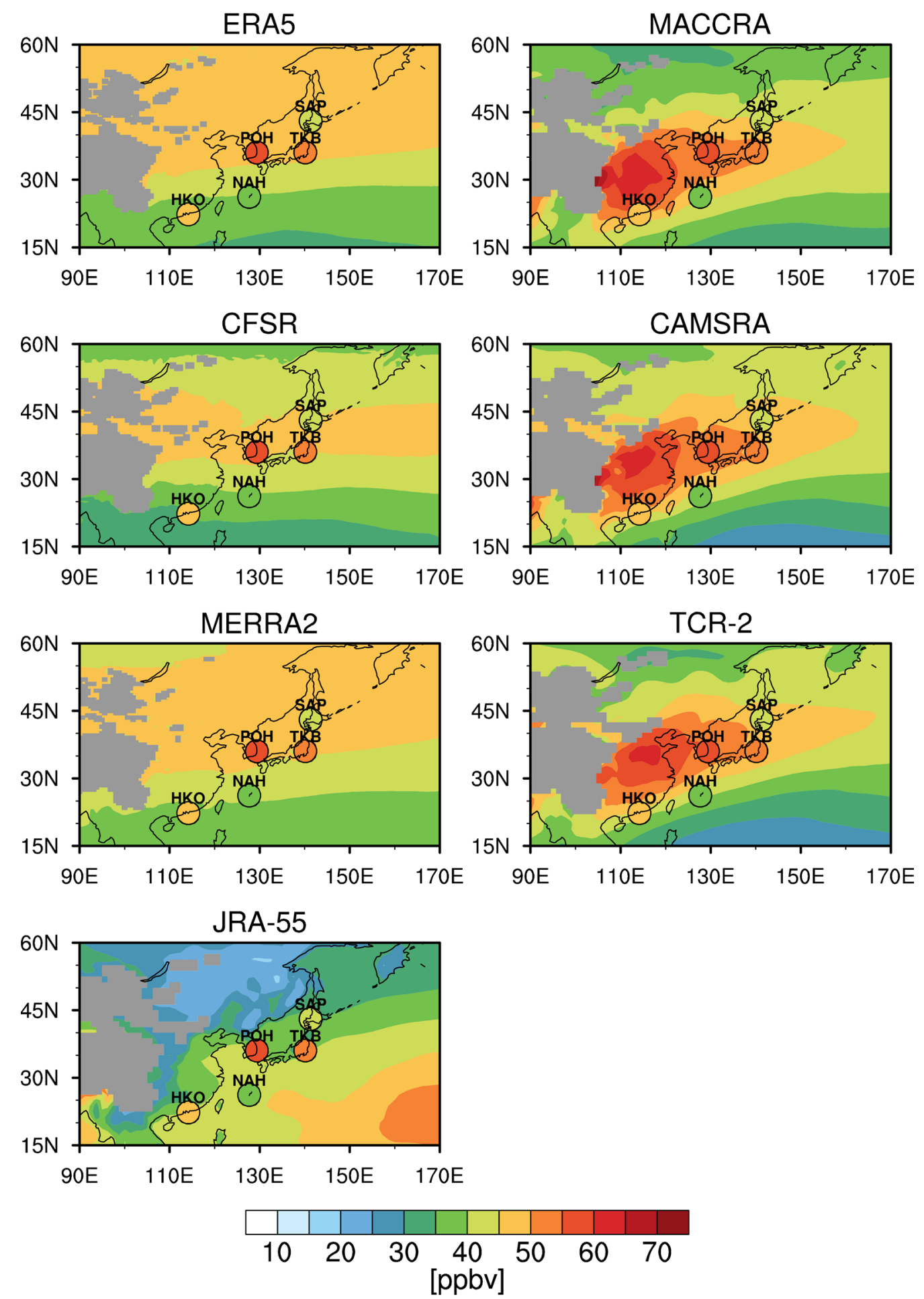

Fig. 1 Climatology of 850-hPa ozone mixing ratio (unit: ppbv) from seven reanalysis datasets and five ozonesonde stations. Grey shading represents the underground missing values 
SAP

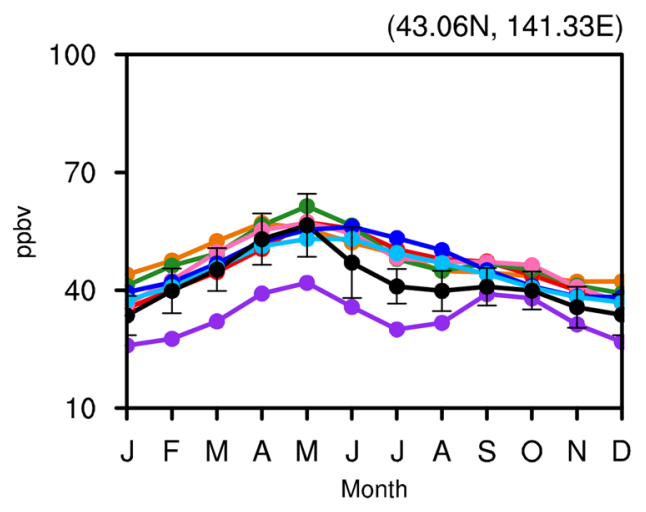

$\mathrm{POH}$

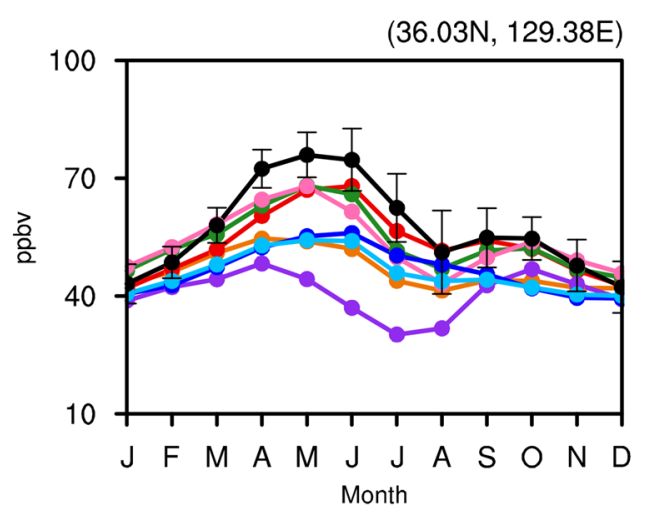

$\mathrm{HKO}$

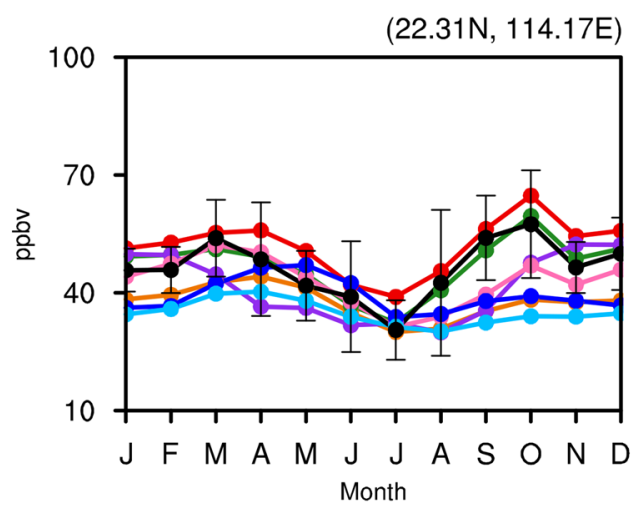

TKB

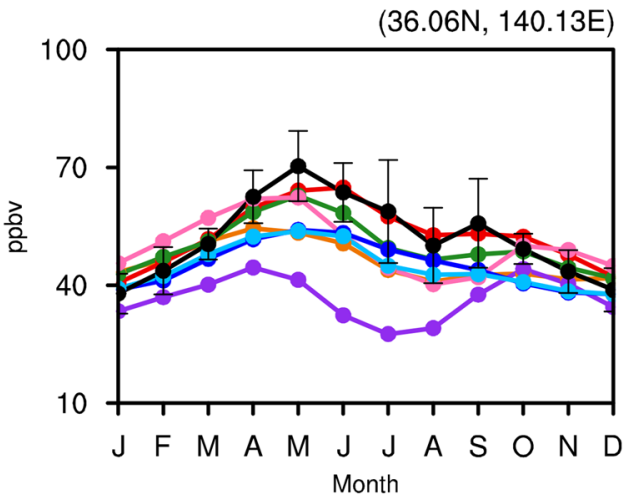

$\mathrm{NAH}$

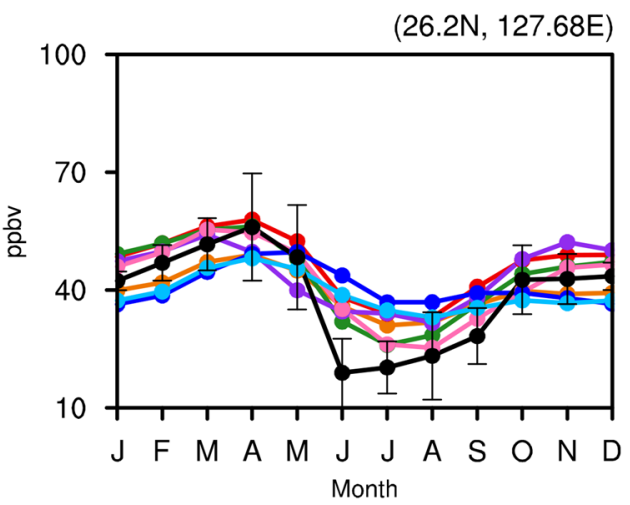

OBS ERA5 MACCRA CAMSRA CFSR MERRA2 JRA-55 TCR-2

Fig. 2 Seasonal cycle of 850-hPa ozone mixing ratio (unit: ppbv) from observation (black), ERA5 (orange), MACCRA (red), CAMSRA (green), CFSR (light blue), MERRA2 (blue), JRA-55 (purple), and TCR-2 (pink) at five ozonesonde stations. The error bars indicate observed one standard deviation on interannual time scale 
Fig. S2). Although most reanalyses show a better match with the observation at $500 \mathrm{hPa}$, MACCRA, CAMSRA, and TCR-2 still exhibit the relatively small biases compared to other datasets. The annual-mean biases of the two groups of reanalyses with and without the chemical transport model are $3.7 \pm 0.6 \%$ and $7.3 \pm 1.9 \%$, respectively, for five ozonesonde observations.

To understand the nature of tropospheric ozone biases, it is worth discussing an observed seasonality of 850$\mathrm{hPa}$ ozone concentration shown in Fig. 2. Four out of the five stations show a maximum ozone concentration in spring ( $>50 \mathrm{ppbv})$ and a minimum ozone concentration in either summer or winter $(<50 \mathrm{ppbv})$. The springtime high ozone concentration is partly attributed to a larger amount of downward ozone transport from the stratosphere (Li et al. 2007) and an enhanced local photochemical production (Dufour et al. 2015). A low ozone concentration during summer is partially due to an abundant moisture and precipitation associated with Asian summer monsoon (Ding et al. 2008; Dufour et al. 2015).

A different seasonality between stations in Fig. 2 could be attributed to the latitudinal location of ozonesonde stations (Tanimoto et al. 2005; Myhre et al. 2013). The HKO station exhibits a relatively high ozone concentration in late fall and winter. This is primarily sourced by the long-range ozone transport from the continent (Lam et al. 2001). The midlatitude stations (i.e., POH, TKB, and SAP), however, show a minimum ozone concentration in winter. This minimum is likely caused by weak photochemical production (e.g., Liu et al. 2015) and rapid chemical transport by strong atmospheric circulation (Yamaji et al. 2006). A distinct seasonal cycle of ozone concentration, which is slightly different from $850 \mathrm{hPa}$, also appears at $500 \mathrm{hPa}$ (Additional file 1: Fig. S2).

Figure 3 shows the vertical profile of ozone mixing ratio from 1000 to $300 \mathrm{hPa}$ at each ozonesonde station with reanalysis dataset (see also Additional file 1: Fig. S3). All reanalysis datasets qualitatively well capture the seasonal evolution of vertical ozone distribution. A high ozone concentration in the upper troposphere (above $400 \mathrm{hPa}$ ), principally transported not from the troposphere but from the stratosphere, is observed. In addition, a relatively low concentration exists near the surface at all ozonesonde stations. Although tropical tropopause is maintained at $\sim 100 \mathrm{hPa}$ and higher in all seasons, midlatitude tropopause exhibits a significant seasonal cycle with a higher tropopause height in summer and a lower tropopause height in winter (e.g., Fig. 5 of Son et al. 2011). Around East Asia, the wintertime tropopause locates around at $\sim 300-\mathrm{hPa}$ pressure level.

The mean bias of each reanalysis data is quantified in Fig. 4 and Additional file 1: Fig. S4. A relatively large positive bias pronounces in JRA-55 from the mid- to upper troposphere. In addition, a negative bias appears from surface to the lower troposphere at all stations and seasons. Note that the bias patterns of MERRA2, CFSR and ERA5 differ from that of JRA-55 (compare 7th column with 2nd, 5th, and 6th columns in Fig. 4 and Additional

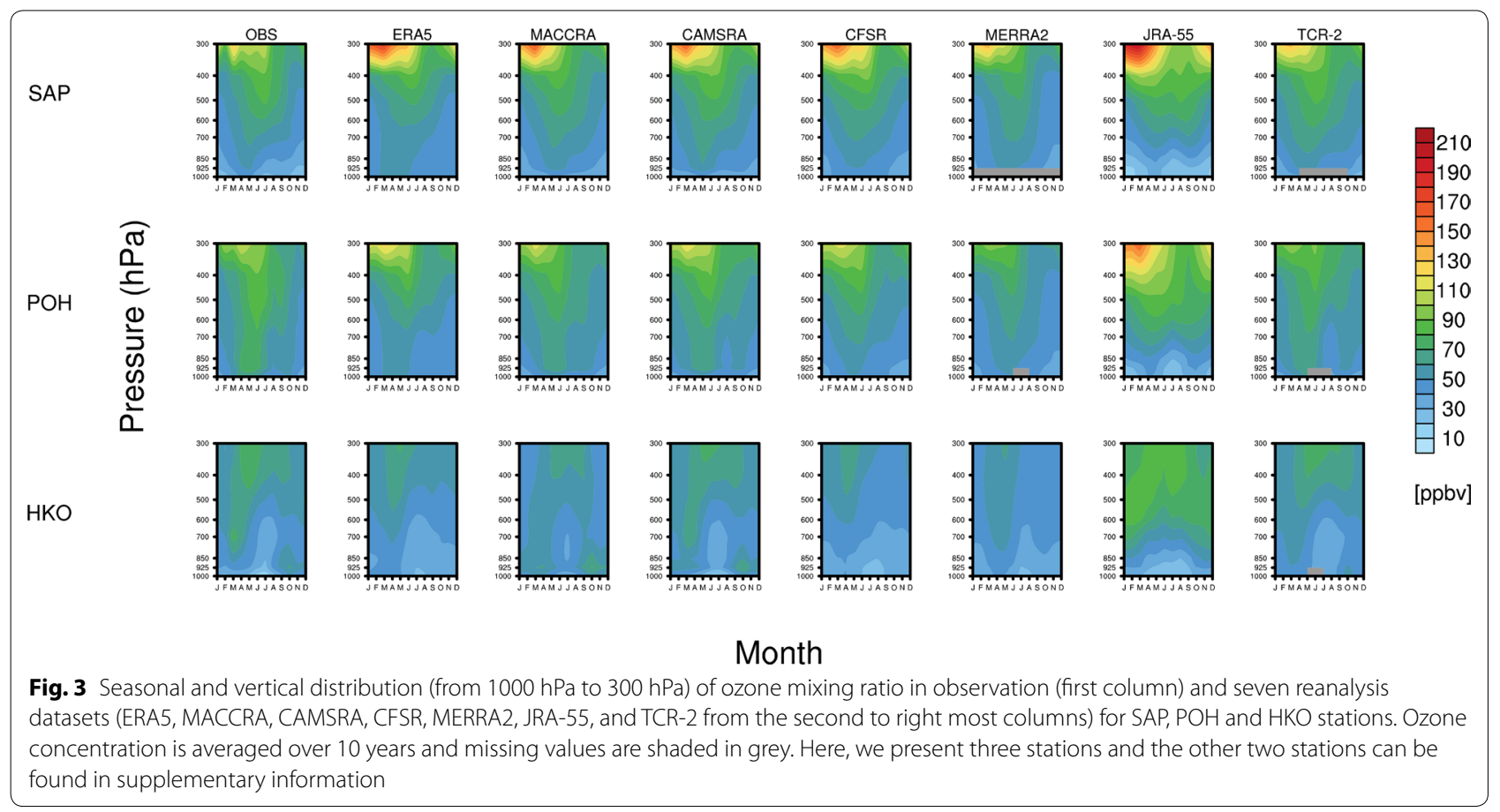




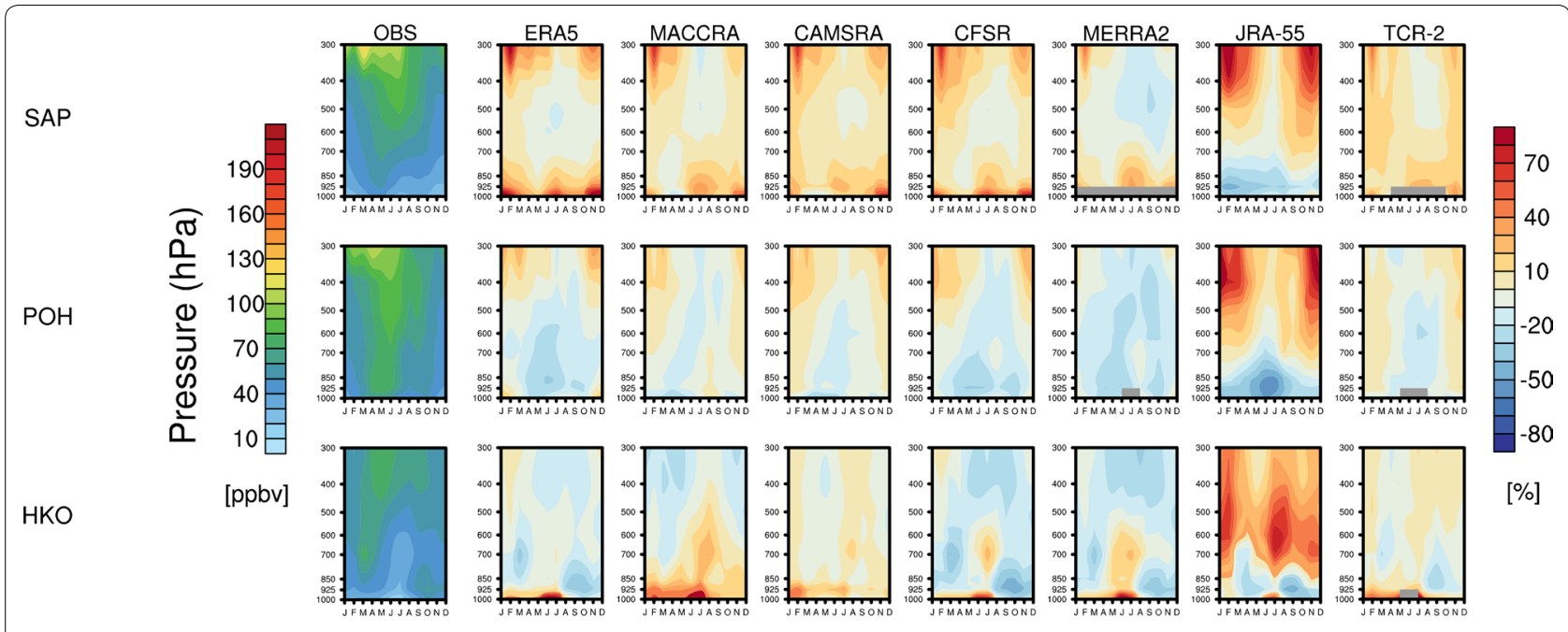

Month

Fig. 4 Same as Fig. 3 but for relative biases (units: \%, from 2nd column). Note that the first column is identical to that in Fig. 2 and shown here as a reference. The relative bias is defined as (reanalysis-ozonesonde)/ozonesonde $\times 100$ for each month. Here, we present three stations and the other two stations can be found in supplementary information

file 1: Fig. S4). These datasets slightly underestimate lower-tropospheric ozone at most stations. As an exception, SAP and NAH display overestimation during the warm season. Among these reanalyses, a smaller bias appears in the reanalyses, which are assimilated with both total column ozone and ozone vertical ozone profile. Huijnen et al. (2020) show that a large ozone bias could be related to the lack of direct tropospheric ozone. Therefore, a possible reason of the bias in JRA- 55 can be attributed to the use of only total column ozone for data assimilation.

To quantify overall biases, the percentage biases shown in Fig. 4 and Additional file 1: Fig. S4 are vertically integrated from $300 \mathrm{hPa}$ to $1000 \mathrm{hPa}$ and averaged over 12 months. The resulting values are then averaged across the five stations. It turns out that JRA- 55 has the largest bias of $19.4 \pm 9.2 \%$. The ERA5, MERRA2 and CFSR show much smaller errors with $9 \pm 1.1,12.7 \pm 1.5$, and $10.4 \pm 2.9 \%$ errors compared to JRA-55, but larger than MACCRA $(6.4 \pm 1.3 \%)$, CAMSRA $(7.8 \pm 2.7 \%)$, and TCR-2 (7.8 $\pm 2.8 \%)$ (Additional file 1: Table S2).

The percentage biases are also evaluated at the two vertical layers, i.e., one in the lower troposphere (below $500 \mathrm{hPa}$ ) and the other in the upper troposphere (500 to $300 \mathrm{hPa}$ ). The JRA- 55 yields the largest bias of $17.7 \pm 9.2 \%$ in the lower troposphere and $34 \pm 2.6 \%$ in the upper troposphere. The CAMSRA shows the smallest biases with $9.5 \pm 4.2 \%$ in the lower troposphere and TCR-2 yields the smallest with $6.3 \pm 1 \%$ in the upper troposphere. The other chemical transport model-based reanalysis,
MACCRA, yields $11.2 \pm 7.4 \%$ in the lower troposphere ( $2^{\text {nd }}$ smallest) and $10.7 \pm 1.8 \%$ in the upper troposphere. Other reanalyses without a chemical transport model produce a larger bias than these three reanalyses (except ERA5 in the upper troposphere). This result suggests that MACCRA, CAMSRA and TCR-2 ozone data have smaller uncertainties than other reanalysis ozone data especially in the lower troposphere.

Figure 5 summarizes $850-\mathrm{hPa}$ ozone bias in reanalyses in terms of correlation coefficient, normalized standard deviation, and normalized root mean-square error at the five ozonesonde stations. The deseasonalized monthlymean ozone data are used to construct a Taylor diagram. It turns out that CAMSRA and TCR-2 have a smaller bias than MACCRA at most stations (Fig. 5a). Inness et al. (2019) also indicated that CAMSRA has a relatively small mean bias and standard deviation compared with MACCRA in global domain. Comparison of the three best reanalyses shows slightly better results from CAMSRA (Fig. 5a). Four stations show a statistically significant and relatively higher correlation with ozonesonde. The normalized standard deviation and root mean-square error of CAMSRA are smaller than 0.6 and 1.0, respectively. Huijnen et al. (2020) indicated that CAMSRA performs statistically better than TCR-2 at $850 \mathrm{hPa}$ in Japan. Not surprisingly, other datasets exhibit larger errors than these three reanalyses (compare Fig. 5a, b). A few reanalyses show even a negative correlation. A similar but smaller error presents at $500 \mathrm{hPa}$ (Additional file 1: Fig. S5). 


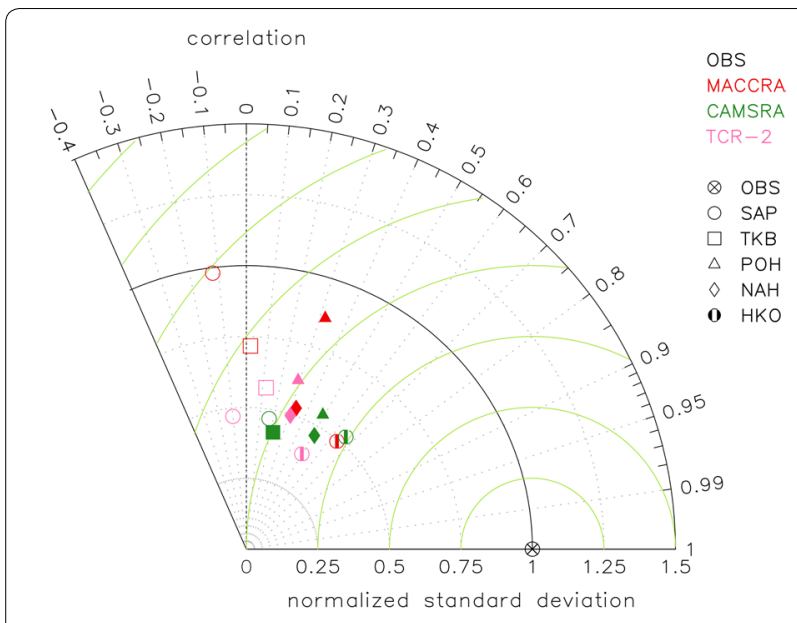

a

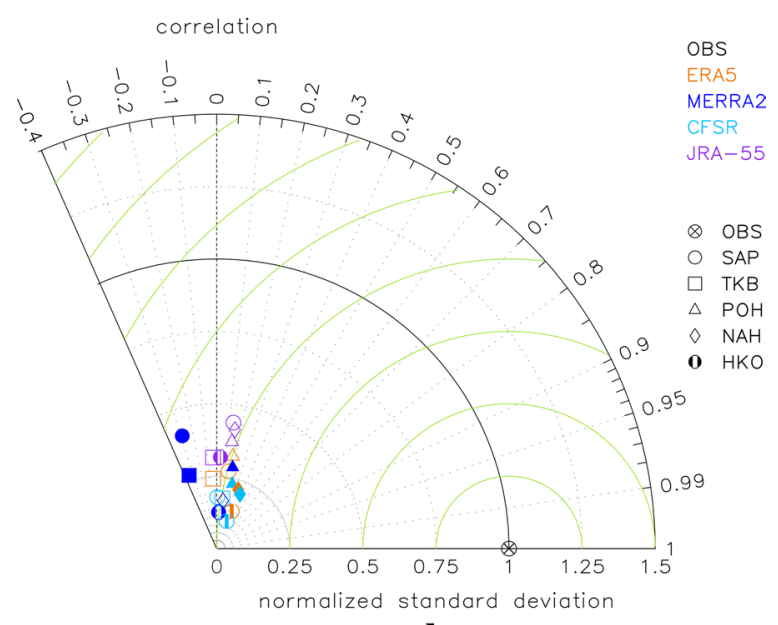

b

Fig. 5 Taylor diagram comparing five ozonesonde observations (circle: SAP, square: TKB, triangle: $\mathrm{POH}$, rhombus: $\mathrm{NAH}$, and circle with thick black lines: HKO) with a MACCRA (red), CAMSRA (green) and TCR-2 (pink); b ERA5 (orange), MERRA2 (blue), CFSR (light blue), and JRA-55 (purple) at $850 \mathrm{hPa}$. The correlation coefficient (indicated at the circumference) that is statistically significant at the $95 \%$ confidence level is denoted with a filled circle

We further examine the decadal trend of deseasonalized ozone concentration at $850 \mathrm{hPa}$ (Fig. 6). When averaged across five stations, the observed ozone in East Asia shows a significantly positive trend of $4.9 \pm 7.9 \mathrm{ppbv}$ decade $^{-1}$ for the period of 2003-2012 (black bars in Fig. 6a, b) and $6.4 \pm 6$ ppbv decade ${ }^{-1}$ for 2003-2017 (Fig. 6c, d). These results agree well with the previous findings of increasing ozone trend over East Asia (Chang et al. 2017; Gaudel et al. 2018). Figure 6a, c shows the decadal trend from 10- and 15-year datasets of reanalyses with a chemical transport model. None of the three reanalyses produce the same trend with similar magnitude as observation except for $\mathrm{POH}$ station (Fig. 6a, c). No decadal trend exists in TCR-2 and CAMSRA. They show the different trends in magnitude or/and in sign. Similar results are obtained with other datasets (Fig. 6b, d). The magnitude of reanalysis trend is smaller by a factor of two. Although the decadal trend at $500 \mathrm{hPa}$ displays slightly better results (Additional file 1: Fig. S6), these results indicate that the use of reanalysis data in longterm ozone trend studies needs a great caution.

\section{Conclusions}

The present study evaluates tropospheric ozone derived from seven reanalysis datasets, i.e., ERA5, MACCRA, CAMSRA, CFSR, MERRA2, JRA-55, and TCR-2 against long-term ozonesonde observations in East Asia. For 850-hPa ozone concentration, MACCRA, CAMSRA, and TCR-2, which incorporate a chemical transport model, yield a better agreement with observations than the other four reanalyses. An annual-mean bias between reanalyses with and without a chemical transport model is $3.7 \pm 0.6 \%$ and $7.3 \pm 1.9 \%$, respectively. These three reanalyses also exhibit more realistic spatial distribution with a maximum ozone concentration in eastern China and its extension to the downstream region. This implies that they well capture tropospheric ozone dispersion along with local emission and transport.

Between the three reanalyses with better performance, TCR-2 and CAMSRA show relatively small mean biases in most analyses than MACC. Both CAMSRA and MACCRA use the same emission data, but different chemical mechanisms and wet/dry deposition. This could be the cause for the differences between CAMSRA and MACCRA performances. With respect to the percentage bias of tropospheric column ozone, MACC shows the smallest bias with $6.4 \pm 1.3 \%$, followed by CAMSRA $(7.8 \pm 2.7 \%)$ and TCR-2 (7.8 $\pm 2.8 \%)$. Moreover, in the two atmospheric layers, CAMSRA shows the smallest biases with $9.5 \pm 4.2 \%$ in the lower troposphere and TCR- 2 yields the smallest with $6.3 \pm 1 \%$ in the upper troposphere. These all three reanalyses, however, fail to reproduce the longterm ozone trends since 2003. This result indicates that the latest reanalysis datasets are still not suitable for the long-term ozone trend analysis in East Asia.

The other four reanalyses, ERA5, CFSR, MERRA2, and JRA-55, poorly represent the spatial distribution of tropospheric ozone. These results indicate that the tropospheric ozone from these reanalyses is not suitable even for seasonal and interannual ozone analyses. This result implies that the reanalysis without chemical transport model has limitation to express the ozone transportation in the lower troposphere.

Our results reveal two key points. The reanalyses incorporated with a chemical transport model and 


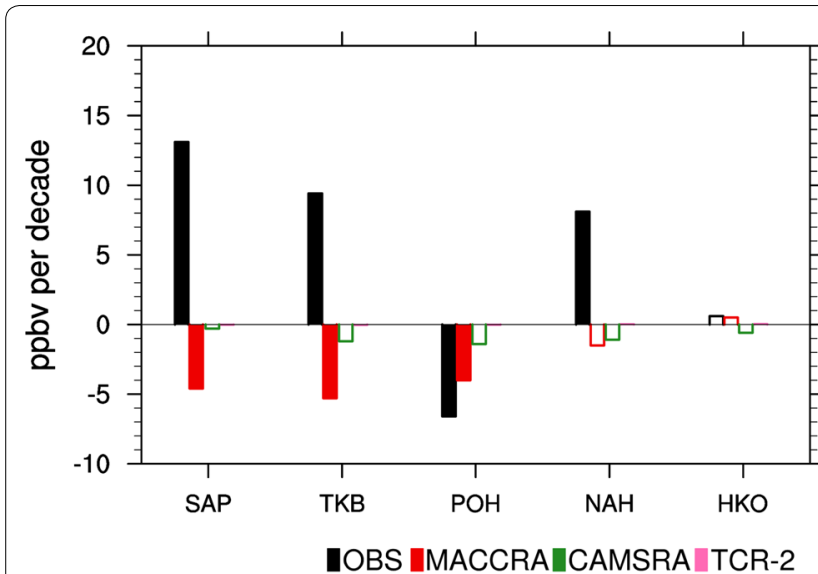

a

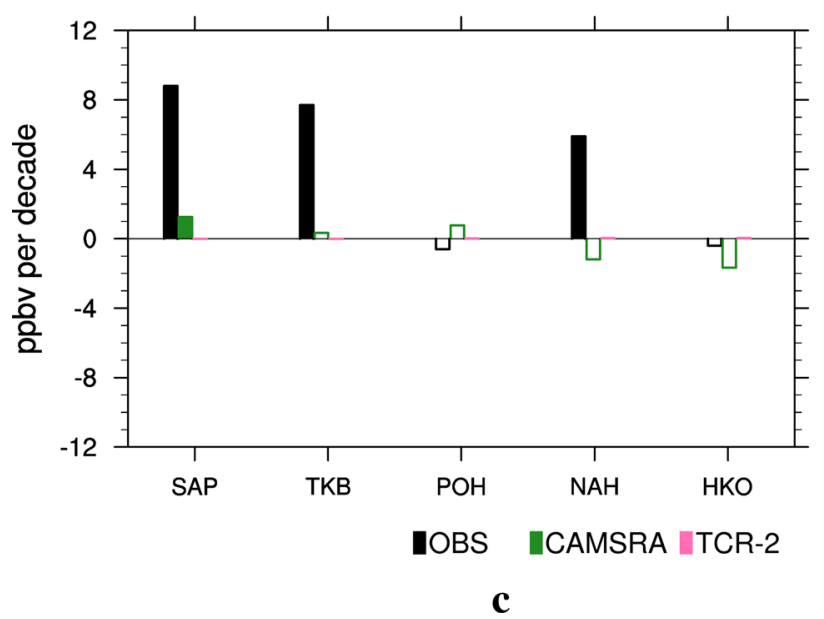

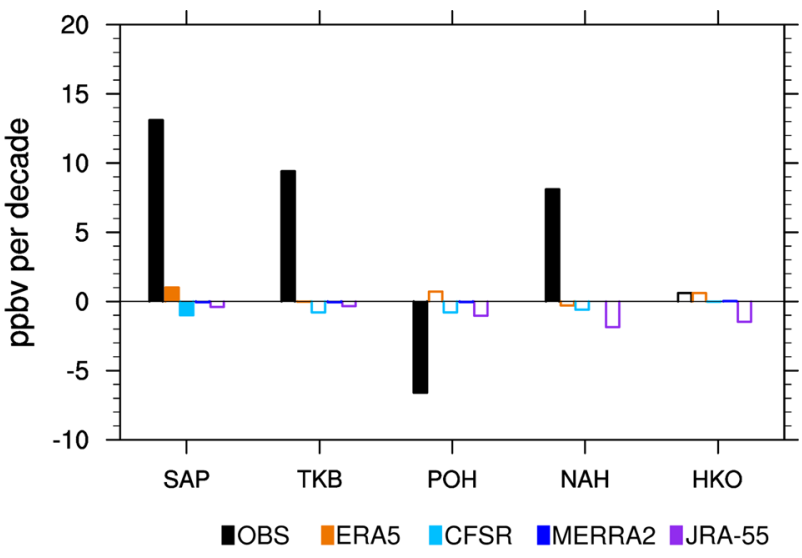

b

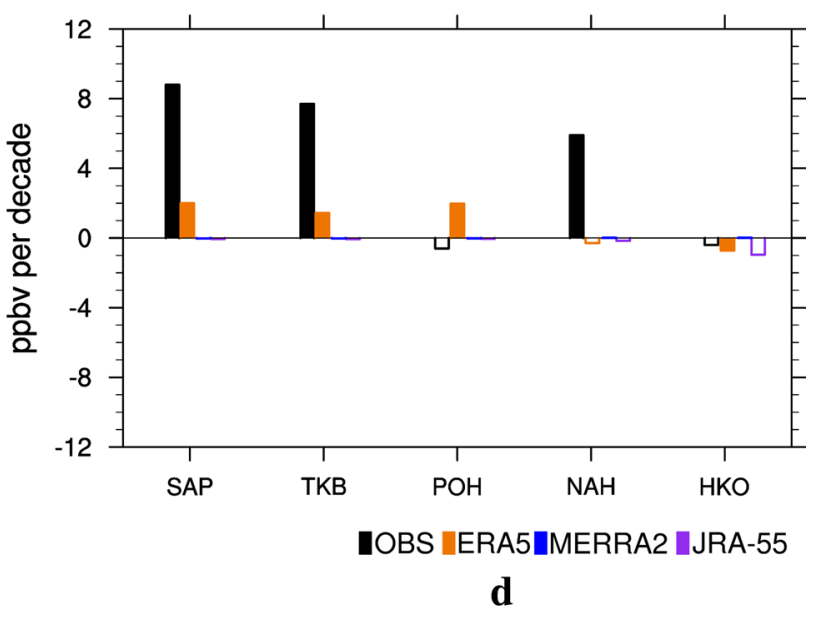

Fig. 6 Decadal trend of deseasonalized monthly-mean 850-hPa ozone mixing ratio (unit: ppbv decade-1) at five ozonesonde stations: observation (black), MACCRA (red), CAMSRA (green), JRA-55 (purple), TCR-2 (pink), ERA5 (orange), CFSR (light blue), and MERRA2 (blue): a, b for 10 years over 2003-2012 and c, d for 15 years over 2003-2017. Note that CFSR is analyzed with only 8-year data from 2003 to 2010 and TCR-2 is considered from 2005. The trend that is statistically significant at the $95 \%$ confidence level is denoted with a filled bar. A two-tailed t-test is used to assess the statistical significance

assimilating both total column and vertical profile of ozone satellite observations produce significantly improved tropospheric ozone in East Asia. Another point of this study is that the chemical transport modelincorporated reanalysis still has limitation to reproduce tropospheric ozone particularly in the long-term trend. These reanalyses consider atmospheric composition and meteorology as well as interaction processes between gas phase and aerosol. This complicated process produces better tropospheric ozone than the one without it. However, the processes could also yield imbalance among coupled reanalysis components, various sources (e.g., wind and precipitation) of systemic error from satellite assimilation, and limited implementation of complex tropospheric chemistry. Therefore, further advances with assimilating various atmospheric components are essential in reanalyses.

\section{Supplementary information}

Supplementary information accompanies this paper at https://doi. org/10.1186/s40562-020-00161-9.

Additional file 1. Additional figures and tables.

\section{Abbreviations}

ECMWF: European Centre for Medium-range Weather Forecasts; ERA5: ECMWF reanalysis 5th generation; MACCRA: Monitoring Atmospheric Composition and Climate Reanalysis; CAMSRA: Copernicus Atmosphere Monitoring Service Reanalysis; MERRA2: Modern-Era Retrospective Analysis for Research and Applications version 2; CFSR: Climate Forecast System Reanalysis; JRA-55: Japanese 55-year Reanalysis; TCR-2: Updated Tropospheric Chemistry Reanalysis; IPCC: Intergovernmental Panel on Climate Change; IASI: Infrared atmospheric 
sounding interferometer; IFS: Integrated forecasting system; MOZART3: Model for Ozone and Related chemical Tracers version 3; CB05: Carbon bond; CTM TM5: Chemistry Transport Model Tracer Model 5; MRI-CCM1: Meteorological Research Institute Chemistry-Climate Model version 1; SBUV: Solar backscatter ultraviolet; TOMS: Total ozone mapping spectrometer; TES: Tropospheric emission spectrometer; MOPITT: Measurements of pollution in the troposphere; OMI: Ozone monitoring instrument; MLS: Microwave limb sounder; GEOS: Goddard Earth Observing System; NRL CHEM2D-OPP: Naval Research Laboratory CHEM2D-Ozone Photochemistry Parameterization; HKO: Hongkong; NAH: Naha; POH: Pohang; SAP: Sapporo; TKB: Tsukuba; WOUDC: World Ozone and Ultraviolet Radiation Data Centre; WMO: World Meteorological Organization; KMA: Korea Meteorological Administration; GEOS: Goddard Earth Observing System; CHASER: Chemical AGCM for Study of atmospheric Environment and Radiative forcing; EnKF: Ensemble Kalman filter.

\section{Acknowledgements}

We are grateful to the WOUDC, KMA, ECMWF, NCEP, JMA, NASA and JAMSTEC for providing ozonesonde observations and reanalysis datasets.

\section{Authors' contributions}

PS prepared initial draft, relevant figures/tables, and wrote the main manuscript. JMI provided relevant figures, contributed to the structure of the article, and provided critical insights on the analysis. PJ conducted data checking and preparation, produced figures relevant to spatial and vertical distribution of tropospheric ozone. PS contributed to the structure of the manuscript. SSW initiated the idea of this study, contributed to the structure of the article, and write-up of the manuscript. All authors read and approved the final manuscript.

\section{Funding}

This work was funded by the Korea Meteorological Administration Research and Development Program under Grant KMI2018-01112.

\section{Availability of data and materials}

The ozonesonde data used in this study come from WOUDC (World Ozone and Ultraviolet Radiation Data Centre: https://woudc.org/home.php) and KMA (Korea Meteorological Administration: http://web.kma.go.kr/eng/index.jsp). The ozone mixing ratio is derived from three different organizations including ECMWF (European Centre for Medium-Range Weather Forecasts: https://www. ecmwf.int/en/forecasts/datasets/browse-reanalysis-datasets), NCAR (National Center for Atmospheric Research: https://climatedataguide.ucar.edu/climatedata/climate-forecast-system-reanalysis-cfsr), JMA (Japanese Meteorological Agency: https://rda.ucar.edu/datasets/ds628.1/), NASA (National Aeronautics and Space Administration: https://gmao.gsfc.nasa.gov/reanalysis/MERRA-2/ data_access/) and JAMSTEC (Japan Agency for Marine-Earth Science and Technology: https://ebcrpa.jamstec.go.jp/tcr2/download.html). The data are available in the aforestated websites.

\section{Competing interests}

The authors declare that they have no competing interests.

\section{Author details}

${ }^{1}$ School of Earth and Environmental Sciences, Seoul National University, 1 Gwanak-ro, Gwanak-gu, Seoul 08826, South Korea. ${ }^{2}$ School of Urban and Environmental Engineering, Ulsan National Institute of Science and Technology, Ulsan, South Korea.

Received: 9 January 2020 Accepted: 29 July 2020

Published online: 12 August 2020

\section{References}

JAMSTEC:TCR-2 reanalysis data, available at: http://ebcrpa.jamstec.go.jp/tcr2/ download.html. Accessed: 23 May 2019

Beekman M, Ancellet G, Megie G, Smit HGJ, Kley D (1994) Intercomparison campaign of vertical ozone profiles including electrochemical sondes of ECC and Brewer-Mast type and a ground-based UV-differential absorption lidar. J Atmos Chem 19:259-288. https://doi.org/10.1007/BF006 94614
Brown-Steiner B, Hess P (2011) Asian influence on surface ozone in the United States: a comparison of chemistry, seasonality, and transport mechanisms. J Geophys Res 116:D17309. https://doi.org/10.1029/2011JD015846

Cariolle D, Deque M (1986) Southern hemisphere medium-scale waves and total ozone disturbances in a spectral general circulation model. J Geophys Res 91:10825-10846. https://doi.org/10.1029/JD091iD10p10825

Cariolle D, Teyssèdre H (2007) A revised linear ozone photochemistry parameterization for use in transport and general circulation models: multi-annual simulations. Atmos Chem Phys 7:2183-2196. https://doi. org/10.5194/acp-7-2183-2007

Chang KL, Petropavlovskikh I, Cooper OR, Schultz MG, Wang T (2017) Regional trend analysis of surface ozone observations from monitoring networks in eastern North America, Europe and East Asia. Elem Sci Anth. 5:50. https ://doi.org/10.1525/elementa.243

Ding AJ, Wang T, Thouret V, Cammas J, Nédélec P (2008) Tropospheric ozone climatology over Beijing: analysis of aircraft data from the MOZAIC program. Atmos Chem Phys 8:1-13. https://doi.org/10.5194/acp-8-1-2008

Dufour G, Eremenko M, Cuesta J, Doche C, Foret G, Beekmann M, Cheiney A, Wang Y, Cai Z, Liu Y, Takigawa M (2015) Springtime daily variations in lower-tropospheric ozone over east Asia: the role of cyclonic activity and pollution as observed from space with IASI. Atmos Chem Phys 15:10839-10856. https://doi.org/10.5194/acp-15-10839-2015

Fiore AM, West JJ, Horowitz LW, Naik V, Schwarzkopf MD (2008) Characterizing the tropospheric ozone response to methane emission controls and the benefits to climate and air quality. J Geophys Res Atmos. https://doi. org/10.1029/2007JD009162

Flemming J, Inness A, Flentje H, Huijnen V, Moinat P, Schultz MG, Stein O (2009) Coupling global chemistry transport models to ECMWF's integrated forecast system. Geosci Model Dev Discuss. 2(253-265):2009. https://doi. org/10.5194/gmdd-2-763-

Flemming J, Benedetti A, Inness A, Engelen RJ, Jones L, Huijnen V, Remy S, Parrington M, Suttie M, Bozzo A, Peuch VH (2017) The CAMS interim reanalysis of carbon monoxide, ozone and aerosol for 2003-2015. Atmos Chem Phys 17:1945-1983. https://doi.org/10.5194/acp-17-1945-2017

Gaudel A, Cooper OR, Ancellet G, Barret B, Boynard A, Burrows JP, Clerbaux C, Coheur PF, Cuesta J, Cuevas Agulló E, Doniki S (2018) Tropospheric ozone assessment report: present-day distribution and trends of tropospheric ozone relevant to climate and global atmospheric chemistry model evaluation. Elem Sci Anth. 6:39. https://doi.org/10.1525/elementa.291

Gelaro R, McCarty W, Suárez MJ, Todling R, Molod A, Takacs L, Randles CA, Darmenov A, Bosilovich MG, Reichle R, Wargan K (2017) The modern-era retrospective analysis for research and applications, version 2 (MERRA-2). J Clim 30:5419-5454. https://doi.org/10.1175/JCLI-D-16-0758.1

Hersbach, H., and Coauthors (2019) Global reanalysis: goodbye ERA-Interim, hello ERA5. ECMWF, https://doi.org/10.21957/vf291 hehd7. https://www. ecmwfint/node/19027

Huijnen V, Williams JE, van Weele M, Van Noije TP, Krol MC, Dentener FJ, Segers A, Houweling S, Peters W, de Laat J, Boersma F (2010) The global chemistry transport model TM5: description and evaluation of the tropospheric chemistry version 3.0. Geosci Model Dev. 3:445-473. https://doi. org/10.5194/gmd-3-445-2010

Huijnen V, Miyazaki K, Flemming J, Inness A, Sekiya T, Schultz MG (2020) An intercomparison of tropospheric ozone reanalysis products from CAMS, CAMS interim, TCR-1, and TCR-2. Geosci Model Dev. 13:1513-1544. https ://doi.org/10.5194/gmd-13-1513-2020

Hunt BR, Kostelich EJ, Szunyogh I (2007) Efficient data assimilation for spatiotemporal chaos: a local ensemble transform Kalman filter. Phys D 230:112-126. https://doi.org/10.5194/gmd-2019-297

Inness A, Baier F, Benedetti A, Bouarar I, Chabrillat S, Clark H, Clerbaux C, Coheur P, Engelen RJ, Errera Q, Flemming J (2013) The MACC reanalysis: an 8 year data set of atmospheric composition. Atmos Chem Phys 13:4073-4109. https://doi.org/10.5194/acp-13-4073-2013

Inness A, Ades M, Agusti-Panareda A, Barré J, Benedictow A, Blechschmidt AM, Dominguez JJ, Engelen R, Eskes H, Flemming J, Huijnen V (2019) The CAMS reanalysis of atmospheric composition. Atmos Chem Phys 19:3515-3556. https://doi.org/10.5194/acp-19-3515-2019

Kanaya Y, Miyazaki K, Taketani F, Miyakawa T, Takashima H, Komazaki Y, Pan X, Kato S, Sudo K, Inoue J, Sato K, Oshima K (2019) Ozone and carbon monoxide observations over open oceans on R/V Mirai from $67^{\circ} \mathrm{S}$ to $75^{\circ} \mathrm{N}$ during 2012 to 2017 : testing global chemical reanalysis in terms of Arctic processes, low ozone levels at low latitudes, and pollution 
transport. Atmos Chem Phys 19(11):7233-7254. https://doi.org/10.5194/ acp-2018-1354

Katragkou E, Zanis P, Tsikerdekis A, Kapsomenakis J, Melas D, Eskes H, Flemming J, Huijnen V, Inness A, Schultz MG, Stein O (2015) Evaluation of near-surface ozone over Europe from the MACC reanalysis. Geosci Model Dev. 8:2299-2314. https://doi.org/10.5194/gmd-8-2299-2015

Kim JH, Lee HJ, Lee SH (2006) The characteristics of tropospheric ozone seasonality observed from ozone soundings at Pohang. Korea. Environ Monit Assess. 118:1-12. https://doi.org/10.1007/s10661-006-0772-7

Kobayashi S, Ota Y, Harada Y, Ebita A, Moriya M, Onoda H, Onogi K, Kamahori H, Kobayashi C, Endo H, Miyaoka K, Takahashi K (2015) The JRA-55 Reanalysis: general specifications and basic characteristics. J Meteor Soc Japan. 93:5-48. https://doi.org/10.2151/jmsj.2015-001

Lam KS, Wang TJ, Chan LY, Wang T, Harris J (2001) Flow patterns influencing the seasonal behavior of surface ozone and carbon monoxide at a coastal site near Hong Kong. Atmos Environ 35:3121-3135. https://doi. org/10.1016/S1352-2310(00)00559-8

Li J, Wang Z, Akimoto H, Gao C, Pochanart P, Wang X (2007) Modeling study of ozone seasonal cycle in lower troposphere over East Asia. J Geophys Res 112:D22S25. https://doi.org/10.1029/2006jd008209

Liu Y, Zhang Y, Wang Y, Liu C, Cai Z, Konopka P, Müller R (2015) Dominant modes of tropospheric ozone variation over East Asia from GOME observations. Adv Meteorol. 2015:879578. https://doi.org/10.1155/2015/87957 8

Lombardozzi D, Levis S, Bonan G, Hess PG, Sparks JP (2015) The influence of chronic ozone exposure on global carbon and water cycles. J Clim 28:292-305. https://doi.org/10.1175/JCLI-D-14-00223.1

McCormack JP, Eckermann SD, Siskind DE, McGee TJ (2006) CHEM2D-OPP: a new linearized gas phase photochemistry parameterization for high altitude NWP and climate models. Atmos Chem Phys 6:4943-4972. https ://doi.org/10.5194/acp-6-4943-2006

Miyazaki K, Bowman K (2017) Evaluation of ACCMIP ozone simulations and ozonesonde sampling biases using a satellite based multi-constituent chemical reanalysis. Atmos Chem Phys 17:8285-8312. https://doi. org/10.5194/acp-17-82852017

Miyazaki K, Sekiya T, Fu D, Bowman KW, Kulawik SS, Sudo K, Walker T, Kanaya Y, Takigawa M, Ogochi K, Eskes H, Boersma KF, Thompson AM, Gaubert B, Barre J, Emmons LK (2019) Balance of emission and dynamical controls on ozone during KORUS-AQ from multi-constituent satellite data assimilation. J Geophys Res: Atmos. 124:387-413. https://doi.org/10.1029/2018J D028912

Miyazaki K, Bowman K, Sekiya T, Eskes H, Boersma F, Worden H, Livesey N, Payne VH, Sudo K, Kanaya Y, Takigawa M (2020) An updated tropospheric chemistry reanalysis and emission estimates, TCR-2, for 2005-2018. Data Discuss, Earth Syst Sci Data. https://doi.org/10.5194/essd-2020-30

Monks PS, Archibald AT, Colette A, Cooper O, Coyle M, Derwent R, Fowler D, Granier C, Law KS, Mills GE, Stevenson DS (2015) Tropospheric ozone and its precursors from the urban to the global scale from air quality to short-lived climate forcer. Atmos Chem Phys 15:8889-8973. https://doi. org/10.5194/acp-15-8889-2015

Myhre G, Shindell D, Pongratz I (2013) Anthropogenic and Natural Radiative Forcing. In: Stocker TF, Qin D, Plattner G-K, Tignor M, Allen SK, Boschung J, Nauels A, Xia Y, Bex V, Midgley PM (eds) Climate change 2013: the physical science basis. Contribution of working group i to the fifth assessment report of the intergovernmental panel on climate change. Cambridge University Press, Cambridge

Parrish DD, Lamarque JF, Naik V, Horowitz L, Shindell DT, Staehelin J, Derwent R, Cooper OR, Tanimoto H, Volz-Thomas A, Gilge S (2014) Long-term changes in lower tropospheric baseline ozone concentrations: comparing chemistry-climate models and observations at northern midlatitudes.
J Geophys Res: Atmos. 119:5719-5736. https://doi.org/10.5194/acpd12.13881-2012

Ramsey NR, Klein PM, Moorelll B (2014) The impact of meteorological parameters on urban air quality. Atmos Environ 86:58-67. https://doi. org/10.1016/j.atmosenv.2013.12.006

Rienecker MM, Suarez MJ, Todling R, Bacmeister J, Takacs L, Liu H-C, Gu W, Sienkiewicz M, Koster RD, Gelaro R, Stajner I, and Nielsen JE (2008) The GEOS-5 Data Assimilation System-Documentation of versions 5.0.1, 5.1.0, and 5.2.0, NASA Tech. Rep. Series on Global Modeling and Data Assimilation. NASA/TM-2008-104606. 27:92

Saha S, Moorthi S, Pan HL, Wu X, Wang J, Nadiga S, Tripp P, Kistler R, Woollen J, Behringer D, Liu H (2010) The NCEP climate forecast system reanalysis. Bull Amer Meteorol Soc. 91:1015-1058. https://doi.org/10.1175/2010B AMS3001.1

Scott CE, Monks SA, Spracklen DV, Arnold SR, Forster PM, Rap A, Äijälä M, Artaxo P, Carslaw KS, Chipperfield MP, Ehn M (2018) Impact on short-lived climate forcers increases projected warming due to deforestation. Nat Commun 9:157. https://doi.org/10.1038/s41467-017-02412-4

Shibata K, Deushi M, Sekiyama TT, Yoshimura H (2005) Development of an MRI chemical transport model for the study of stratospheric chemistry. Pap Meteor Geophys. 55:75-119. https://doi.org/10.2467/mripapers.55.75

Son SW, Tandon NF, Polvani LM (2011) The fine-scale structure of the global tropopause derived from COSMIC GPS radio occultation measurements. J Geophys Res: Atmos. 116:D20. https://doi.org/10.1029/2011JD016030

Sudo K, Takahashi M, Kurokawa Jl, Akimoto H (2002) CHASER: a global chemical model of the troposphere 1. Model description. J Geophys Res Atmos. 107:D17. https://doi.org/10.1029/2001JD001113

Tanimoto H, Sawa Y, Matsueda H, Uno I, Ohara T, Yamaji K, Kurokawa Jl, Yonemura S (2005) Significant latitudinal gradient in the surface ozone spring maximum over East Asia. Geophys Res Lett 32:L21805. https://doi. org/10.1029/2005GL023514

Wargan K, Pawson S, Olsen MA, Witte JC, Douglass AR, Ziemke JR, Strahan SE, Nielsen JE (2015) The global structure of upper troposphere-lower stratosphere ozone in GEOS-5: a multiyear assimilation of EOS Aura data. J Geophys Res: Atmos. 120:2013-2036. https://doi.org/10.1002/2014J D022493

Wargan K, Labow GS, Frith S, Pawson S, Livesey N, Partyka G (2017) Evaluation of the ozone fields in NASAs MERRA-2 reanalysis. J Climate. 30:2961-2988. https://doi.org/10.1175/JCLI-D-16-0699.1

World Meteorological Organization (2007), Scientific assessment of ozone depletion: 2006, Rep. 50, Global Ozone Res. Monitor. Proj., World Meteorol.Org., Geneva, Switzerland

World Meteorological Organization-Global Atmosphere Watch Program (WMO-GAW)/World Ozone and Ultraviolet Radiation Data Centre (WOUDC) [Data]. Retrieved October 24, 2013. https://woudc.org. A list of all contributors is available on the website. https://doi.org/10.14287 $/ 10000001$

Yamaji K, Ohara T, Uno I, Tanimoto H (2006) Analysis of the seasonal variation of ozone in the boundary layer in East Asia using the community multiscale air quality model: what controls surface ozone levels over Japan? Atmos Environ 40:1856-1868. https://doi.org/10.1016/j.atmos env.2005.10.067

Yarwood G, Rao S, Yocke M, and Whitten G (2005) Updates to the carbon bond chemical mechanism: CB05, Final report to the US EPA, EPA Report Number: RT-0400675. http://www.camx.com. Accessed 15 Mar 2019

\section{Publisher's Note}

Springer Nature remains neutral with regard to jurisdictional claims in published maps and institutional affiliations. 